\title{
Analisis Kesiapan Guru dalam Menerapkan Pembelajaran Tematik di Madrasah Ibtidaiyah
}

\author{
Putri Wulan Dhari, ${ }^{*}$ Wajnah, Nova Susanti \\ Institut Agama Islam Negeri Takengon \\ *Penulis korespondensi: putriwulandhari89@gmail.com \\ DOI : https://doi.org/10.21580/jieed.v1i2.7749 \\ Received: 2021-02-28, Revised: 2021-10-15, \\ Accepted: 2021-11-05, Published: 2021-11-05
}

\begin{abstract}
Abstrak
Penelitian ini bertujuan untuk menganalisis dan menjabarkan kesiapan guru Madrasah Ibtidaiyah dalam melaksanakan pembelaran tematik berdasarkan standar yang berlaku. Penelitian ini menggunakan metode kualitatif deskriptif. Subjek penelitiannya adalah guru Madrasah Ibtidaiyah Negeri 10 Aceh Tengah. Data penelitian ini telah diuji keabsahannya menggunakan triangulasi data dan member check, dan dianalisis melalui tahap reduksi data, sajian data, dan penarikan kesimpulan. Hasil penelitian ini menemukan bahwa: 1) sebagian guru yang telah memahami konsep pembelajaran tematik tidak dapat menearapkan pembelajaran tematik; 2) guru telah mampu menyusun rencana pembelajaran tematik dengan baik; 3) guru melaksanakan kegiatan pembelajaran tematik sesuai dengan RPP yang disusunnya, 4) dan metode dan media pembelajaran yang digunakan guru dalam pembelajaran tematik kurang bervariasi, dan 5) guru kurang terampil dalam menyusun rubrik penilaian autentik. Kesulitan guru dalam mengimplementasikan pembelajaran tematik adalah; 1) kondisi sarana belajar yang tidak memadai; 2) sumber belajar dan media yang digunakannya masih sangat terbatas, 3) kesulitan dalam menyusun rubrik penilaian sikap; dan 4) guru kesulitan dalam menguraikan kegiatan pembelajaran yang sesuai dengan pendekatan saintifik.
\end{abstract}

Kata Kunci: kesiapan guru Madrasah Ibtidaiyah, pembelajaran tematik, pembelajaran saintifik, pembelajaran di Madrasah Ibtidaiyah

\section{Analysis of Teacher Readiness in Implementing Thematic Learning in Madrasah Ibtidaiyah}

\section{Abstract}

This study aims to analyze and describe the readiness of Madrasah Ibtidaiyah teachers in carrying out thematic learning based on applicable standards. This research uses 
descriptive qualitative method. The research subject is a teacher at Madrasah Ibtidaiyah Negeri 10 Central Aceh. The validity of this research data has been tested using data triangulation and member check, and analyzed through the stages of data reduction, data presentation, and drawing conclusions. The results of this study found that: 1) some teachers who had understood the concept of thematic learning were unable to apply thematic learning; 2) the teacher has been able to develop a thematic lesson plan well; 3) teachers carry out thematic learning activities in accordance with the RPP they have compiled, 4) and the methods and learning media used by teachers in thematic learning are less varied, and 5) teachers are less skilled in compiling authentic assessment rubrics. The difficulties of teachers in implementing thematic learning are; 1) conditions of inadequate learning facilities; 2) learning resources and media used are still very limited, 3) difficulties in compiling an attitude assessment rubric; and 4) the teacher has difficulty in describing learning activities that are in accordance with the scientific approach.

\section{Keywords: readiness of teacher, thematic learning, scientific approach, teaching and learning at Islamic elementary school}

\section{PENDAHULUAN}

Indonesia mengalami beberapa perubahan kurikulum dalam beberapa dekade terakhir. Kebutuhan masyarakat yang semakin berkembang sesuai tuntutan zaman menjadi salah satu alasan adanya perubahan kurikulum tersebut. Dengan kata lain, perubahan kurikulum bertujuan untuk menjawab kebutuhan masyarakat dalam dunia industri yang mengalami perkembangan signifikan dalam ilmu pengetahuan dan teknologi. Namun, penerapan kurikulum yang baru membutuhkan kerja sama dan komitmen dari berbagai pihak, seperti kepala sekolah, rekan sejawat, dan internal dalam kelas (Magdalena, Vitaloka, Elismawati, dan Aji, 2020).

Saat ini Indonesia menerapkan Kurikulum 2013. Sesuai namanya, kurikulum ini diterapkan di Indonesia mulai tahun 2013 secara bertahap di seluruh Indonesia. Ada beberapa kelebihan dalam Kurikulum 2013, seperti siswa yang dituntut lebih aktif, kreatif dan inovatif, penilaian dari semua aspek, pembelajaran yang bersifat kontekstual, dan sebagainya (Sumilah, 2017). Dengan berbagai kelebihan tersebut, pendidikan di Indonesia, baik tingkat SD/MI, SMP, dan SMA/SMK diharapkan akan menjadi lebih baik lagi dan dapat bersaing di dunia internasional.

Kurikulum di Madrasah Ibtidaiyah sedikit berbeda dengan kurikulum Sekolah Dasar. Hal ini karena Masdrasah Ibtidaiyah memiliki berciri khas Islam sehingga muata materi pelajaran agamanya lebih banyak daripada Sekolah Dasar (Siskandar, 2017). Kurikulum 2013 untuk sekolah dasar dan Madrasah Ibtidaiyah mengandung beberapa karakterisik, yaitu: 1) tematik integratif; 2) enam mata pelajaran; 3) pramuka sebagai ekstrakurikuler wajib; 4) bahasa ingggris adalah kegiatan 
ekstrakulikuler bersama PMR, UKS, dan pramuka; 5) penambahan jam pelajaran (Sunarti dalam Sumilah, 2017).

Pembelajaran tematik adalah pembelajaran terpadu yang memanfaatkan tema tertentu untuk menghubungkan beberapa mata pelajaran sekaligus sehingga diharapkan siswa mendapatkan pengalaman yang lebih bermakna. (Majid, 2017). Lebih lanjut Majid menyebutkan bahwa pemakaian tema dimaksudkan supaya siswa dapat memahami sebuah konsep dengan lebih mudah dan jelas. Selain itu, bermakna artinya siswa diyakini akan menjumpai pengalaman yang lebih nyata sehingga pada akhirnya akan meningkatkan pengetahuan, sikap, dan keterampilan mereka secara nyata pula. Dengan demikian, melalui implementasi pembelajaran tematik diharapkan hasil belajar siswa akan lebih bertahan dalam waktu yang lama atau bersifat jangka panjang.

Dalam pembelajaran tematik pada Kurikulum 2013, guru menggunakan pendekatan saintifik dalam proses pembelajaran. Pendekatan ini memiliki beberapa tahapan kegiatan, yaitu mengamati, menanya, mencoba. menalar, mengomunikasikan. Proses pembelajarannya pun akan menekankan pada tiga bidang, yaitu pengetahuan, keterampilan, dan sikap. Selanjutnya, guru akan menggunakan penilaian autentik dalam mengevaluasi hasil pembelajaran siswa (Kristiantari, 2014).

Ada beberapa hal yang perlu diperhatikan sebelum sekolah menerapkan pembelajaran tematik. Hal ini akan menjadi prinsip yang sifatnya mendasar dan dapat dijadikan pedoman dalam menerapkan pembelajaran tematik. Beberapa prinsip tersebut adalah; 1) berpusat pada anak; 2) pengalaman langsung; 3) tidak tampak pemisahan mata pelajaran; 4) penyajian beberapa mata pelajaran sekaligus dalam sebuah pertemuan pembelajaran; 5) fleksibel; 6) bermakna dan utuh; 7) alokasi waktu dan sumber; 8) tema terdekat dengan siswa; dan 9) pencapaian kompetensi (Kurniawan, 2014).

Guru sebagai pendidik merupakan memiliki peran yang sangat penting dalam keberhasilan pembelajaran tematik. Guru merupakan pendidik profesional yang tugasnya untuk mendidik, membimbing serta mengajarkan ilmu dan pengetahuan kepada siswa dengan tujuan mencerdaskan mereka. Susuai dengan Peraturan Menteri Pendidikan Nasional Republik Indonesia Nomor 16 Tahun 2007 tentang Standar Kualifikasi Akademik dan Kompetensi Guru, dijelaskan bahwa guru kelas $\mathrm{SD} / \mathrm{MI}$ yang profesional adalah guru yang menguasai empat kompetensi guru, yaitu kompetensi pedagogik, kompetensi kepribadian, kompetensi sosial, dan kompetensi professional. Empat kompetensi guru inilah yang diharapkan akan membantu siswa mencapai arah dan tujuan yang sudah ditetapkan.

Dalam proses belajar-mengajar, guru diharapkan dapat berposisi sebagai penengah, sedangkan siswa sendiri yang harus berusaha untuk meningkatkan perubahan kompetensi, baik pengetahuan, keterampilan, maupun sikap yang ada 
dalam dirinya. Secara lebih khusus, guru juga berperan sebagai; 1) pembimbing yang mengarahkan siswa pada kedewasaan; 2) penghubung dengan siswa untuk mengomunikasikan segala hal yang berkaitan dengan peningkatan pengetahuan, keterampilan, dan sikap siswa; 3) penegak disiplin sehingga akan menjadi suri teladan dalam berbagai bidang; dan 4) administrator dan manajer yang mampu mengatur lingkungan belajar sehingga tercipta suasana yang kondusif dan siap pakai untuk proses pembelajaran (Hamid, 2015).

Implementasi pembelajaran tematik ini tentu bukan tanpa kesulitan. Ada banyak guru yang mengeluh sulitnya menerapkan pembelajaran tematik karena banyak hal-hal baru yang berbeda dengan kurikulum sebelumnya yang harus dipelajari dan dipersiapkan oleh guru. Hal ini menyebabkan banyak guru yang masih menggunakan model pembelajaran sebelumnya yang ada dalam Kurikulum Tingkat Satuan Pendidikan (KTSP) (Ariyani, Fauziddin, dan Kusuma, 2019). Untuk itu, guru harus memahami pembelajaran termatik tersebut sebelum mengimplementasikannya.

Perencanaan pembelajaran, pelaksanaan pembelajaran, dan evaluasi hasil pembelajaran yang selaras dengan kurikulum 2013 harus dipahami oleh guru (Rahman dan Bahar, 2019). Oleh karena itu, guru membutuhkan "kesiapan sikap dan emosi, kesiapan pengetahuan, kesiapan perilaku dan kesiapan keterampilan dalam menerapkan pembelajaran tematik" (Linda dan Hadiyanto, 2019). Selain itu, guru juga harus memiliki wawasan yang luas dan kreativitas yang tinggi untuk menyelenggarakan pembelajaran tematik.

Dengan kata lain, guru harus mengekplorasi banyak informasi, menciptakan kreasi, dan mengembangkan inovasi agar materi yang diajarkan tidak hanya berfokus pada satu mata pelajaran saja. Selain itu, guru juga harus menjamin bahwa media yang digunakan juga sesuai dengan materi yang diajarkan, serta alat ukur yang dipakai dapat mengukur kompetensi siswa. Dengan cara inilah keberhasilan penerapan pembelajaran tematik akan lebih memungkinkan untuk tercapai.

Berdasarkan penjelasan di atas, dapat dipahami pembelajaran tematik sangat penting untuk dikuasai guru karena menentukan keberhasilan proses pembelajaran dan hasil belajar siswa. Penguasaan guru terhadap pembelajaran tematik dipengaruhi oleh berbagai hal, salah satunya adalah kesiapan guru dalam mengajar. Kesiapan guru sangat penting karena dalam tujuan Kurikulum 2013, di antaranya mendorong peserta didik mampu lebih baik dalam melakukan observasi, bertanya, mencoba, bernalar, dan berkomunikasi, serta mempresentasikan apa yang mereka peroleh setelah menerima materi pembelajaran.

Dengan demikian, penelitian ini akan mendeskripsikan dan menganalis kesiapan guru dalam pembelajaran tematik di Madrasah Ibtidaiyah Negeri 10 Aceh Tengah. Kesiapan guru yang dijabarkan dalam penelitian ini meliputi perencanaan, 
pelaksanaan, serta evaluasi hasil pembelajaran. Selain itu, artikel ini juga akan membahas kendala yang dihadapi guru dalam mengaktualisasikan pembelajaran tematik.

\section{METODE}

Penelitian ini menggunakan metode kualitatif deskriptif, yang artinya data yang diperoleh dari lapangan akan dideskripsikan dan dipaparkan dengan rinci. Hal ini sesuai dengan definisi metode kualitatif itu sendiri, yaitu penelitian yang datadatanya dikumpulkan dan digunakan prosedur ilmiah, serta lebih mengutamakan makna daripada menggeneralisasikan hasil penelitian (Rohmadi dan Nasucha, 2017). Selanjutnya, subjek penelitian ini adalah guru-guru Madrasah Ibtidaiyah Negeri 10 Aceh Tengah.

Teknik pengumpulan data yang dilakukan berupa observasi, wawancara, dan dokumentasi. Observasi dilakukan dengan mengamati secara langsung kesiapan guru dalam mengaktualisasikan pembelajaran tematik, seperti perencanaan, pelaksanaan, evaluasi, dan hambatan yang ditemui oleh guru dalam mengimplementasikan pembelajaran tematik di dalam kelas. Teknik wawancara digunakan dengan melakukan wawancara terstruktur kepada guru Madrasah Ibtidaiyah Negeri 10 Aceh Tengah. Terakhir, dokumentasi meliputi foto dan video yang diambil saat observasi dan wawancara.

Lebih lanjut lagi, instrumen dalam penelitian ini menggunakan lembar observasi, pedoman wawancara, berikut dokumentasi. Langkah-langkah analisis data dalam penelitian ini adalah reduksi data, sajian data, dan penarikan kesimpulan (Miles \& Huberman dalam Sutopo, 2006). Keabsahan data diuji melalui triangulasi data dan member check. Prosedur penelitian ini terdiri dari tahap reduksi data, sajian data, dan penarikan kesimpulan

\section{HASIL}

Keberhasilan pembelajaran sangat bergantung pada kemampuan guru dalam mempersiapkan pembelajaran tersebut. Perencanaan yang matang tentu akan meningkatkan peluang terciptanya suasana pembelajaran yang aktif, kreatif, dan menyenangkan. Perencanaan pembelajaran yang matang juga ikut menentukan hasil akhir dari pembelajaran tersebut, apakah kemampuan, keterampilan, dan sikap yang didapatkan siswa sudah sesuai dengan target yang ingin dicapai, atau sebaliknya. Tentu, kesiapan guru dalam melaksanakan hal-hal di atas harus didukung pula oleh sekolah sebagai lembaga pendidikan yang menjadi wadah dalam mengembangkan potensi siswa. Dengan demikian, kepala sekolah juga berperan penting dalam membantu kesiapan guru dalam pembelajaran. 
Hasil yang ditemukan dalam penelitian ini berupa kesiapan guru dalam pembelajaran tematik, yang meliputi perencanaan, pelaksanaan, dan penilaian pembelajaran, hambatan yang ditemui guru dalam pembelajaran tematik tersebut, serta cara mereka menyelesaikan hambatan tersebut. Selain itu, temuan penelitian juga didapat melalui hasil wawancara oleh kepala sekolah dan siswa Madrasah Ibtidaiyah Negeri 10 Aceh Tengah. Hasil penelitian ini dapat dijabarkan sebagai berikut.

Secara keseluruhan, kesiapan guru dalam pembelajaran tematik telah berlangsung dengan cukup baik. Hal ini dilihat setelah dilakukannya observasi, wawancara, dan analisis dokumen, yaitu Rencana Pelaksanaan Pembelajaran (RPP) yang dibuat dan digunakan oleh guru-guru Madrasah Ibtidaiyah Negeri 10 Aceh Tengah. Berkaitan dengan perencanaan dalam pembelajaran tematik, guru-guru di Madrasah Ibtidaiyah Negeri 10 Aceh Tengah telah membuat RPP sebelum tahun pelajaran baru dimulai. RPP ini disusun berdasarkan kalender pendidikan, program tahunan (prota), dan program semester (prosem) yang telah disusun sebelumnya.

Lebih lanjut lagi, guru juga telah memastikan bahwa kegiatan-kegiatan pembelajaran yang mereka susun dalam RPP sesuai dengan kompetensi dasar dan indikator yang ingin dicapai. Hasil analisis dokumen juga menunjukkan guru telah mengembangkan RPP berdasarkan kurikulum dan silabus. Selain itu, guru-guru meyakini bahwa RPP yang dibuat telah mempertimbangkan kemampuan awal, potensi, motivasi, minat, dan bakat siswa sehingga kegiatan-kegiatan pembelajaran ini akan lebih bersifat fleksibel dan dapat dilakukan secara optimal antara guru dan siswa. Selanjutnya, tahapan pencapaian siswa yang dikembangkan dalam RPP juga sudah jelas. Begitu pula dengan sistem evaluasi, telah dijabarkan guru dalam RPP. Bahkan, guru juga sudah membuat prosedur program remedial dan program pengayaan bagi siswa yang tidak/belum mencapai kompetensi yang telah ditetapkan.

Berdasarkan keterangan di atas, secara umum perencanaan pembelajaran yang dibuat oleh guru-guru Madrasah Ibtidaiyah Negeri 10 Aceh Tengah sudah baik. Komponen-komponen RPP yang ada di dalamnya juga sudah sesuai dengan pedoman penyusunan RPP. Hanya saja, ada beberapa hal yang tidak dicantumkan dalam RPP tersebut, seperti pendekatan pembelajaran dan sumber belajar. Selain itu, bentuk tes dan kunci jawaban yang digunakan guru juga tidak tercantum detail dalam RPP tersebut. Begitu pula dengan uraian kegiatan yang dibuat tidak rinci.

Selanjutnya, berkaitan dengam pelaksanaan pembelajaran, guru-guru di Madrasah Ibtidaiyah Negeri 10 Aceh Tengah telah melaksanakan kegiatan pembelajaran sesuai dengan RPP yang telah disusun. Seperti yang telah diketahui bahwa secara umum pelaksanaan pembelajaran terbagi menjadi tiga kegiatan, yaitu kegiatan pendahuluan, kegiatan inti, dan kegiatan penutup. Dalam pembelajaran tematik, kegiatan-kegiatan tersebut dilaksanakan sesuai dengan langkah-langkah 
pendekatan saintifik. Berikut adalah hasil penelitian berdasarkan tiga kegiatan tersebut sesuai dengan hasil observasi dan wawancara.

Pertama, kegiatan pendahuluan yang dilakukan oleh guru-guru di Madrasah Ibtidaiyah Negeri 10 Aceh Tengah secara umum adalah berdoa, dilanjutkan dengan mengabsen siswa, kemudian mengondisikan atau mengarahkan siswa pada pembelajaran, menyampaikan tujuan pembelajaran, serta memberi petunjuk kegiatan pembelajaran yang akan dilakukan siswa kepada siswa. Selanjutnya, dalam kegiatan inti, pembelajaran dilaksanakan melalui langkah-langkah dalam pendekatan saintifik, yaitu mengamati (observasi), menanya, mengumpulkan informasi (mencoba), mengasosiasikan (menalar), dan mengomunikasikan.

Melalui analisis dokumen, yaitu RPP yang digunakan guru, juga observasi di dalam kelas, terlihat bahwa guru-guru Madrasah Ibtidaiyah Negeri 10 Aceh Tengah telah melaksanakan pembelajaran sesuai dengan langkah-langkah dalam pendekatan saintifik. Baik dalam RPP maupun proses pembelajaran, langkahlangkah ini terlihat jelas. Hanya saja, tidak semua guru menerapkan semua komponen dari langkah-langkah secara berurutan. Bukan hanya itu, ada pula guru yang tidak menerapkan semua komponen dari langkah-langkah ini. Ada yang hanya menerapkan tiga dari lima komponen, ada pula yang hanya menerapkan empat dari lima komponen. Selain perihal pendekatan pembelajaran, berdasarkan observasi juga ditemukan bahwa tidak tampak adanya pemisahan antarmata pelajaran saat guru mengajar sehingga dapat dikatakan proses pembelajaran yang berlangsung telah sesuai dengan pembelajaran tematik.

Adapun metode pembelajaran yang sering digunakan oleh guru-guru Madrasah Ibtidaiyah Negeri 10 Aceh Tengah berupa metode ceramah, diskusi, tanya jawab, dan jigsaw". Berdasarkan hasil observasi dan wawancara, metode-metode ini adalah metode yang paling tepat untuk diajarkan di Madrasah Ibtidaiyah Negeri 10 Aceh Tengah dan telah disesuaikan dengan kemampuan dan kompetensi siswa dalam mengikuti proses pembelajaran dengan menggunakan metode-metode tersebut.

Adapun media pembelajaran yang digunakan oleh guru-guru Madrasah Ibtidaiyah Negeri 10 Aceh Tengah adalah menyesuaikan dengan materi yang dipelajari. Media tersebut dapat berupa media gambar, flashcard, juga audio-visual. Itu artinya, guru sudah terbiasa mengoperasikan computer untuk menggunakan media tersebut. Guru-guru tersebut juga menekankan bahwa media yang umum mereka gunakan adalah media yang dapat ditemukan di lingkungan sekolah.

Adapun sumber belajar yang digunakan oleh guru dan siswa adalah buku pegangan guru dan siswa yang memang telah disediakan oleh sekolah. Sesuai dengan kurikulum 2013, buku yang digunakan dalam pembelajaran tematik adalah buku tematik. Di dalam buku pegangan guru dan siswa ini, setiap babnya berisi beberapa tema yang sudah disesuaikan dengan kompetensi yang akan dicapai 
siswa. Buku-buku ini tersedia di perpustakaan sekolah. Namun, buku-buku ini masih kurang memadai jumlahnya jika dibandingkan dengan jumlah siswa. Selain itu, sarana prasarana lain, seperti komputer dan infokus juga masih kurang jumlahnya untuk menunjang proses pembelajaran siswa.

Pada kegiatan penutup pembelajaran, guru-guru Madrasah Ibtidaiyah Negeri 10 Aceh Tengah biasanya melaksanakan kegiatan, seperti melakukan umpan-balik, meninjau kembali kegiatan pembelajaran yang sudah dilakukan bersama dengan siswa, menentukan ketercapaian kompetensi siswa melalui kegiatan evaluasi, merencanakan kegiatan tindak lanjut dari hasil evaluasi, dan menyampaikan rencana kegiatan pembelajaran yang akan dilakukan pada pertemuan berikutnya.

Pada proses evaluasi, kegiatan yang dilakukan guru di dalam kelas tidak dijabarkan secara rinci, baik dalam RPP maupun observasi di dalam kelas. Seperti yang diketahui, penilaian siswa dilakukan melalui tiga kategori, yaitu kognitif, psikomotorik, dan afektif. Namun, rata-rata guru hanya fokus pada penilaian kognitif, sedangkan penilaian psikomotorik dan afektif dikesampingkan. Dalam RPP, guru hanya menjabarkan jenis soal yang digunakan dalam penilaian psikomotorik dan afektif, tetapi tidak mencantumkan rubrik penilaian untuk kedua penilaian tersebut. Sebagai tambahan pula. berdasarkan hasil observasi, wawancara, dan analisis dokumen, guru masih sulit dalam mengembangkan penilaian autentik.

Meskipun ada beberapa kekurangan guru dalam mengimplementasikan pembelajaran tematik, tetapi dapat dirumuskan bahwa pada dasarnya guru-guru Madrasah Ibtidaiyah Negeri 10 Aceh Tengah telah memiliki kesiapan dalam pembelajaran tematik. Ketiga kegiatan pembelajaran (pembuka, inti, dan penutup) yang dilaksanakan oleh guru-guru Madrasah Ibtidaiyah Negeri 10 Aceh Tengah dapat diaktualisasikan dengan baik sesuai dengan pedoman baku yang telah ditetapkan pemerintah.

Selanjutnya, berlandaskan hasil penelitian, guru-guru Madrasah Ibtidaiyah Negeri 10 Aceh Tengah juga memiliki kesulitan dalam melaksanakan proses pembelajaran dengan menggunakan pembelajaran tematik. Kesulitan-kesulitan yang dirasakan oleh guru-guru ini diakui memberikan dampak pada sempurna atau tidaknya pembelajaran tematik yang mereka selenggarakan. Beberapa kesulitan ini antara lain sebagai berikut. Pertama, guru sulit menentukan tema yang sesuai yang dapat dikaitkan ke dalam beberapa mata pelajaran sekaligus. Guru menjelaskan bahwa mereka membutuhkan banyak waktu untuk menentukan berbagai tema yang dapat digunakan dalam pembelajaran tematik.

Kedua, guru sering terkendala dalam menentukan media yang akan digunakan. Hal ini disebabkan oleh guru harus memastikan bahwa media yang dipilih adalah alat bantu pembelajaran yang dapat digunakan dalam beberapa mata pelajaran. Ketiga, guru kesulitan dalam menyusun rubrik untuk menilai sikap siswa. Terkait hal ini, guru mengakui belum terlalu memahami bagaimana membuat rubrik 
sikap yang baik dan sesuai dengan kompetensi yang akan diukur. Keempat, sarana dan prasaran yang masih belum memadai membuat guru terhalang dalam mengembangkan pembelajaran tematik. Terakhir, kesulitan dalam menjabarkan uraian kegiatan pembelajaran yang sesuai dengan langkah-langkah pendekatan saintifik. Lima komponen dalam pendekatan saintifik sering dijabarkan tidak berurutan oleh guru di dalam RPP, serta ada pula yang tidak memperlihatkan seluruh komponen dalam pendekatan saintifik.

Hal ini diakui pula oleh Kepala Sekolah Madrasah Ibtidaiyah Negeri 10 Aceh Tengah yang mengamini bahwa ada beberapa faktor yang menyebabkan guru masih kesulitan dalam menyelenggarakan pembelajaran tematik. Namun, untuk mengatasinya kepala sekolah biasanya mengarahkan guru-guru tersebut untuk membentuk kelompok-kelompok kecil atau kegiatan tutor teman sebaya untuk saling berdiskusi mengenai kendala-kendala yang mereka rasakan dan mencari solusinya bersama-sama. Misalnya, guru-guru dapat berdiskusi tentang cara menentukan tema, berdiskusi dalam membuat kegiatan pembelajaran yang berbasis tematik, memilih media yang dapat mengaitkan semua atau beberapa mata pelajaran, juga menentukan bentuk penilaian yang akan digunakan dalam semua kategori penilaian.

\section{PEMBAHASAN}

Berdasarkan hasil penelitian di atas dapat dibahas masing-masing komponen yang diperlukan dalam mematangkan kesiapan guru dalam pembelajaran tematik di Madrasah Ibtidaiyah Negeri 10 Aceh Tengah. Beberapa persiapan yang dilakukan guru di Madrasah Ibtidaiyah Negeri 10 Aceh Tengah, yaitu pertama, perencanaan pembelajaran. Hasil penelitian menunjukkan bahwa perencanaan pembelajaran telah dibuat dengan matang dan tidak terburu-buru. RPP yang dibuat juga sudah berdasarkan kurikulum dan silabus, serta kompetensi dasar dan indikator yang ingin dicapai. Selanjutnya, sebelum membuat RPP, guru sebelumnya telah menganalisis kemampuan awal, potensi, motivasi, minat, dan bakat siswa sehingga kegiatan-kegiatan pembelajaran ini akan lebih bersifat fleksibel dan dapat dilakukan secara optimal antara guru dan siswa. Hal ini sesuai dengan penjelasan Yatmini (2016) bahwa dalam kurikulum 2013 prinsip pengembangan RPP yang perlu diperhatikan salah satunya adalah didasarkan pada ide kurikulum dan silabus, juga menyesuaikan dengan situasi lingkungan siswa, seperti kebutuhan, kemampuan awal, kemampuan sosial, gaya belajar, emosi, motivasi, dan lain-lain.

Selanjutnya, secara umum komponen-komponen RPP yang dibuat oleh guruguru Madrasah Ibtidaiyah Negeri 10 Aceh Tengah sudah sesuai dengan pedoman penyusunan RPP yang ada dalam Permendikbud Nomor 22 Tahun 2016 Tentang Standar Proses Pendidikan Dasar dan Menengah. Hanya saja, ada komponen yang tidak dicantumkan dalam RPP tersebut, seperti pendekatan pembelajaran, sumber 
belajar, bentuk tes dan kunci jawaban, serta uraian kegiatan yang dibuat tidak rinci. Hasil penelitian ini mirip dengan penelitian Ariyani, Fauziddin, dan Kusuma (2019) yang menyebutkan dalam penelitiannya bahwa dalam RPP-nya, guru tidak menyebutkan pendekatan pembelajaran yang digunakan.

Pembahasan kedua adalah pelaksanaan pembelajaran. Pelaksanaan pembelajaran yang dilakukan guru Madrasah Ibtidaiyah Negeri 10 Aceh Tengah meliputi kegiatan pendahuluan, kegiatan inti, dan kegiatan penutup. Hal ini telah sesuai dengan Permendikbud Nomor 22 Tahun 2016 yang menyebutkan bahwa langkah-langkah pembelajaran dalam RPP terdiri atas pendahuluan, inti, dan penutup. Selain itu, temuan ini juga serupa dengan penelitian Ariyani, Fauziddin, dan Kusuma (2019). Pada kegiatan pendahuluan, guru sudah menjalankan tugas dan perannya dengan mempersiapkan siswa untuk menerima pembelajaran. Pada kegiatan inti, guru telah melaksanakan pembelajaran sesuai dengan langkahlangkah dalam pendekatan saintifik. Namun, sepertinya guru masih kesulitan dalam menerapkan langkah-langkah pendekatan saintifik. Hal ini terlihat dengan adanya urutan yang tidak sesuai antara langkah-langkah dengan penerapan yang dilaksanakan guru di dalam kelas, bahkan ada pula guru yang tidak menerapkan semua komponen pendekatan tersebut. Hasil serupa diperoleh pula oleh Ariyani, Fauziddin, dan Kusuma (2019) yang menjelaskan bahwa guru masih belum mampu mengurutkan langkah-langkah pendekatan saintifik dalam proses pembelajaran.

Selanjutnya, guru sudah mampu mengajar dengan pembelajaran tematik dengan tidak memperlihatkan pemisahan antarmata pelajaran. Dengan demikian, hasil ini telah sesuai dengan Permendikbud Nomor 57 Tahun 2014 tentang Kurikulum 2013 SD/MI, juga serupa dengan penelitian Linda dan Hadiyanto (2019) bahwa guru-guru SDN Baruah Gunuang sudah mampu memadupadankan beberapa mata pelajaran ke dalam satu tema. Namun, berlawanan dengan hal ini, penelitian Astiningtyas (2018) justru membuktikan bahwa masih ada guru yang kesulitan dalam menyampaikan pembelajaran kolaborasi dengan tema.

Lebih mendalam lagi, metode pembelajaran yang sering digunakan oleh guruguru Madrasah Ibtidaiyah Negeri 10 Aceh Tengah berupa metode ceramah, diskusi, tanya jawab, dan jigsaw. Namun seharusnya, metode pembelajaran yang digunakan guru bisa lebih bervariasi dari itu. Misalnya, guru dapat menambahkan metode inkuiri atau discovery learning yang dapat lebih menunjang keberhasilan proses pembelajaran dalam kurikulum 2013 dan pembelajaran tematik. Dengan demikian, siswa diharapkan lebih aktif dan dapat mengembangkan kemampuan mereka untuk memecahkan masalah yang dihadapi. Selain itu, metode-metode tersebut membuat peran guru menjadi lebih krusial karena guru diharapkan dapat mendorong peserta didik untuk mampu melakukan observasi, menanya, mencoba, menalar, dan mengomunikasikan apa yang mereka peroleh setelah menerima materi pembelajaran (Rahman dan Bahar, 2019). 
Berikutnya, terkait dengan media pembelajaran, yang paling sering digunakan guru Madrasah Ibtidaiyah Negeri 10 Aceh Tengah adalah media gambar, flashcard, juga audio-visual. Hasil wawancara dengan guru menjelaskan bahwa mereka kesulitan dalam menentukan media yang akan digunakan dalam pembelajaran tematik. Hal ini juga dibenarkan oleh kepala sekolah bahwa guru sering merasa kesulitan dalam memilih atau membuat tema yang dapat digunakan dalam beberapa mata pelajaran sekaligus. Kesulitan ini tidak hanya dirasakan oleh guruguru Madrasah Ibtidaiyah Negeri 10 Aceh Tengah, tetapi juga guru-guru lain seperti yang diungkapkan dalam penelitian lainnya yang akan dibahas kemudian.

Melanjuti paragraf sebelumnya, sumber belajar yang digunakan guru dan siswa di Madrasah Ibtidaiyah Negeri 10 Aceh Tengah diketahui jumlahnya masih belum mencukupi, seperti buku pegangan guru dan siswa, juga komputer dan infokus yang disediakan sekolah masih minim. Komputer sering digunakan guru sebagai alat bantu dalam pembelajaran tematik, tetapi diketahui pula ada beberapa guru yang masih kurang mampu mengoperasikannya karena berbabagi sebab, seperti keterbatasan pengetahuan dan usia guru yang sudah cukup lanjut. Hal ini sejalan pula dengan penelitian Astiningtyas (2018) yang memaparkan bahwa guru masih belum mampu menguasai teknologi karena terkendala umur guru yang sudah tua. Namun, hasil ini bertolang belakang dengan penelitian Linda dan Hadiyanto (2019) yang membuktikan bahwa guru-guru SDN Baruang Gunuang sudah mampu mengoperasikan komputer meskipun belum terlalu mahir.

Dalam kegiatan ketiga, yaitu kegiatan penutup yang tak kalah pentingnya, guru sudah melakukan tugas dan perannya dengan baik. Hanya saja, guru belum mampu membuat alat ukur yang sesuai dalam penilaian psikomotorik dan afektif. Guru tidak mencantumkan rubrik penilaian untuk kedua penilaian tersebut. Selain itu, keahlian guru dalam membuat penilaian autentik masih kurang. Padahal penilaian autentik adalah penilaian yang memiliki peranan yang penting dalam kurikulum 2013 seperti isi Permendikbud Nomor 22 Tahun 2016 yang menyatakan bahwa "penilaian proses pembelajaran menggunakan pendekatan penilaian autentik yang menilai kesiapan peserta didik, proses, dan hasil belajar secara utuh". Hasil yang hampir mirip juga ditemukan dalam penelitian Rahman dan Bahar (2019) yang menyatakan bahwa guru masih kesulitan dalam menerapkan penilaian autentik untuk kegiatan proses dan hsil belajar.

Pembahasan terakhir adalah tentang kesulitan atau hambatan yang ditemui guru dalam mempersiapkan dan mengimplemntasikan pembelajaran tematik. Beberapa kesulitan itu adalah pertama, guru sulit menentukan tema yang sesuai yang dapat dikaitkan ke dalam beberapa mata pelajaran sekaligus. Kesulitan ini ditemui pula dalam penelitian terdahulu (Nuraini dan Abidin, 2020). Kedua, guru terkendala dalam menentukan media yang akan digunakan. Kesulitan dalam memilih media ini sepertinya juga banyak terjadi di beberapa daerah lain, seperti 
dalam beberapa penelitian sebelumnya, Nuraini dan Abidin (2020), Linda dan Hadiyanto (2019), dan Ariyani, Fauziddin, dan Kusuma (2019).

Ketiga, ketidakmampuan guru dalam membuat rubrik dalam penilaian sikap. Hal ini senada dengan hasil penelitian lain yang memaparkan bahwa guru di SDN Sukasari 4 belum maksimal dalam menerapkan penilaian autentik. Hal ini disebabkan oleh beberapa faktor, seperti guru yang terlalu fokus pada materi yang disampaikan, metode pengisian instrumen penilaian yang memberatkan guru, dan guru yang merasa membuang banyak waktu untuk membuat deskripsi keberhasilan siswa (Magdalena, Vitaloka, Elismawati, dan Aji, 2020).

Keempat, sarana dan prasarana yang masih minim dan keterampilan dalam mengoperasikannya. Temuan yang sama juga terdapat dalam penelitian sebelumnya bahwa guru masih kaku dalam mengoperasikan komputer atau laptop untuk pembelajaran (Linda dan Hadiyanto, 2019). Kelima, guru masih sulit dalam menjabarkan uraian kegiatan pembelajaran yang sesuai dengan langkah-langkah pendekatan saintifik. Hal ini selaras dengan hasil penelitian terdahulu yang dilakukan oleh Rahman dan Bahar (2019) dan Ariyani, Fauziddin, dan Kusuma (2019).

Strategi guru mengatasi kesulitan-kesulitan di atas adalah dengan membentuk kelompok-kelompok kecil bersama rekan sejawat, berdiskusi mengenai hal tersebut dan bersama-sama mencari solusinya. Namun, tentu hal ini tidaklah cukup. Hal yang diinginkan guru-guru Madrasah Ibtidaiyah Negeri 10 Aceh Tengah adalah adanya pelatihan-pelatihan terkait peningkatkan kemampuan dalam pembelajaran tematik. Hal serupa juga disampaikan oleh guru-guru sekolah dasar di Provinsi Bali dalam penelitian Kristiantari (2014). Hasil penelitiannya menyebutkan bahwa harapan guru agar diberikan pelatihan mengenai kurikulum 2013 berkategori "sangat tinggi", yaitu sebesar 97,57\%. Mereka berujar bahwa ceramah dan sosialisasi tidak cukup mampu dalam meningkatkan kemampuan guru. Lebih lanjut lagi, sekolah dan pemerintah daerah setempat dapat membentuk team teaching sehingga guru dapat berdiskusi dengan rekan sejawatnya mengenai pembelajaran tematik.

\section{SIMPULAN}

Hasil penelitian ini menunjukkan bahwa guru Madrasah Ibtidaiyah Negeri 10 Aceh Tengah telah memiliki kesiapan dalam mengaktualisasikan pembelajaran tematik. Di sisi lain, guru masih perlu melakukan beberapa perbaikan yang berkaitan dengan penggunaan metode dan media pembelajaran. Oleh karena itu, diperlukan kerja sama kepala sekolah dan pemerintah daerah untuk mengatasi kekurangan-kekurangan ini, seperti membuat pelatihan-pelatihan bagi guru untuk meningkatkan pengetahuan dan keterampilan mereka dalam pembelajaran tematik, mengedukasi guru untuk belajar dari berbagai sumber di internet, dan menyediakan sarana dan prasarana sekolah lebih banyak lagi. 


\section{DAFTAR PUSTAKA}

Akbar, Sa'dun. dkk. 2017. Implementasi Pembelajaran Tematik di Sekolah Dasar. Bandung: PT Remaja Rosdakarya.

Astiningtyas, Anna. (2018). Kesiapan Guru Sekolah Dasar dalam Pelaksanaan Pembelajaran Tematik Integratif pada Kurikulum 2013. Jurnal Primary, 7 (1), 60-67.

Darmadi, Hamid. (2015). 'Tugas, Peran, Kompetensi, dan Tanggung Jawab Menjadi Guru Profesional", Jurnal Edukasi, 13 (2), 161-174.

Kristiantari, Rini. (2014). Analisis Kesiapan Guru Sekolah Dasar dalam Mengimplementasikan Pembelajaran Tematik Integratif Menyongsong Kurikulum 2013. Jurnal Pendidikan Indonesia, 3 (2), 460-470.

Kurniawan, Deni. (2019). Pembelajaran Terpadu Tematik (Teori, Praktik, dan Penilaian). Bandung: Alfabeta.

Linda, Silvia Citra dan Hadiyanto. (2019) Kesiapan Dan Kemampuan Guru dalam Menerapkan Pembelajaran Tematik Terpadu di Sekolah Dasar Gugus 01 Baruah Gunuang. JURNAL BASICEDU: Research \& Learning in Elementary Education, 3 (2), 524-532.

Magdalena, Ina, Vitaloka, Diah, Elismawati, dan Aji, Khaerina Sasmita. (2020) Implementasi Kurikulum 2013 di Sekolah Dasar bagi Perkembangan Peserta Didik dI SDN SUKASARI 4. Jurnal Halaqah, 2 (2), 116-125.

Majid, Abdul. (2017). Pembelajaran Tematik Terpadu. Bandung: PT Remaja Rosdakarya.

Nuraini dan Abidin, Zainal. (2020). Kesulitan Guru dalam Mengimplementasikan Pembelajaran Tematik Terintegratif di Sekolah Dasar. Premiere Educandum: Jurnal Pendidikan Dasar dan Pembelajaran, 10 (1), 49 - 62.

Peraturan Menteri Pendidikan Nasional Republik Indonesia Nomor 16 Tahun 2007, Standar Kualifikasi Akademik dan Kompetensi Guru

Peraturan Menteri Pendidikan dan Kebudayaan Republik Indonesia Nomor 57 Tahun 2014, Kurikulum 2013 Sekolah Dasar/Madrasah Ibtidaiyah

Peraturan Menteri Pendidikan dan Kebudayaan Nomor 22 Tahun 2016, Standar Proses Pendidikan Dasar dan Menengah.

Rahman, Abdul dan Bahar, Syamsul. (2019). Kesiapan Sekolah dalam Mengimplementasikan Kurikulum 2013: Studi Deskriptif di Kecamatan Palu Barat dan Palu Timur Kota Palu. JIP: Jurnal Inspirasi Pendidikan, 9 (2), 110-116

Rohmadi, Muhammad dan Nasucha, Yakub. (2017). Dasar-dasar penelitian Bahasa, Sastra, dan Pengajaran. Surakarta: Pustaka Briliant 
Siskandar. (2017, 21 Januari). Analisis Peran Guru dan Kepala Madrasah dalam Mengimplementasikan Kurikulum 2013. Dipresentasikan dalam Seminar Nasional: Kupas Tuntas Kurikulum 2013, Semarang, Jawa Tengah.

Sumilah. (2017, 21 Januari). Implementasi Kurikulum 2013 dalam Pendidikan Karakter di Sekolah Dasar. Dipresentasikan dalam Seminar Nasional: Kupas Tuntas Kurikulum 2013, Semarang, Jawa Tengah.

Sutopo, H.B. (2006). Metodologi Penelitian Kualitatif: Dasar Teori dan Terapannya dalam Penelitian. Surakarta: Universitas Sebelas Maret

Yatmini. (2016). Meningkatkan Kompetensi Guru dalam Penyusunan RPP yang Baik dan Benar melalui Pendampingan Berbasis KKG Semester Satu Tahun 2016/2017 Di SD Negeri Model Mataram. JIME: Jurnal Imliah Pendidikan, Sosial, dan Politik, 2 (2), 172-184. 